http://ojs.borneo.ac.id/ojs/index.php/JBKB

ISSN 2685-0753 (cetak)

ISSN 2685-2039 (online)

\title{
KARAKTER IDEAL KONSELI DALAM PRAKTEK KEARIFAN LOKAL MASYARAKAT DESA
}

\author{
Rury Muslifar ${ }^{1}$, Andi Wahyu Irawan ${ }^{2}$ \\ Bimbingan Konseling, Universitas Mulawarman \\ andiwahyuirawan@fkip.unmul.ac.id
}

\begin{abstract}
Abstrak
Penelitian ini bertujuan untuk mengidentifikasi kearifan lokal desa Melan yang akan dijadikan sebagai indikator dalam menentukan karakter ideal konseli atau siswa. Praktek kearifan lokal masyarakat desa Melan dalam mempertahankan dan melestarikan hutan ditengah maraknya perkebunan sawit dan tambang merupakan sesuatu yang menarik untuk diteliti jika dibandingkan dengan daerah disekitarnya yang kondisi hutannya sudah memprihatinkan. Sebagai kandidat kampung iklim plus di Kalimantan Timur, desa Melan memiliki praktek kearifan lokal yang perlu untuk didentifikasi dan diadopsi dalam pendidikan sebagai upaya solutif terhadap dampak negatif perkembangan teknologi. Metode penelitian menggunakan penelitian kualitatif etnografi. Hasil penelitian menunjukkan pribadi ideal konseli dalam praktek kearifan lokal desa Melan yaitu (1) pribadi yang setiakawan, (2) memiliki keyakinan pada tuhan, ruh, manusia dan alam, dan (3) kebiasaan hidup sederhana. Saran dari penelitian ini diharapkan dijadikan sebagai rekomendasi dalam merancang indikator pribadi ideal konseli atau siswa di desa Melan hingga skala tingkat Kecamatan Long Mesangat.
\end{abstract}

Kata Kunci : Pribadi Ideal, Konseli, Kearifan Lokal, Melan

\section{PENDAHULUAN}

Karakter merupakan perwujudan diri yang secara utuh membentuk keunikan setiap manusia. Karakter diperlukan sebagai supaya solutif terhadap pengaruh negatif diera distrupsi. Dunia pendidikan perlu mengadopsi karakter ideal untuk dijadikan sebagai aspek pengembangan afeksi, terutama profesi konselor (guru bimbingan konseling) yang bekerja pada ranah non kognisi.

Penelitian ini didasari atas fakta bahwa terdapat kearifan lokal yang dipraktekkan oleh warga desa Melan yang sudah mengakar dalam kebiasaan kehidupan sehari-hari. Implikasi dari praktek kearifan lokal tersebut membuat desa Melan menjadi kampung iklim yang berhasil 
mempertahankan kawasan hutan ditengah perkembangan perkebunan sawit dan maraknya pertambangan.

Pemuda sebagai penerus tongkat estapet masa depan desa Melan, perlahanlahan mulai meninggalkan kearifan lokal yang dipraktekkan oleh pendahulunya. Terjadi pergeseran nilai di desa Melan yang disinyalir disebabkan oleh transfer pengetahuan antara orang tua ke anak yang tidak terjadi dengan baik sehingga mengakibatkan praktek kearifan lokal semakin berkurang. Menghargai orang yang lebih tua, gotong royong, santun, bekerja keras, dan tekun menjadi bagian kecil dari nilai-nilai kearifan lokal yang mulai ditinggalkan. Fakta bahwa sebagian besar generasi muda di desa Melan perlahan-lahan meninggalkan kampung halaman untuk merantau dan tidak kembali lagi, adalah sebuah ancaman bagi desa Melan karena akan berdampak terhadap munculnya berbagai masalah sosial.

Perubahan tatanan sosial yang terjadi di desa Melan tidak lepas dari perkembangan teknologi yang semakin pesat, ditambah lagi dengan masuknya perusahaan tambang dan masyarakat pendatang yang semakin menggeser identitas masyarakat desa Melan. Efendi (2009) mengatakan bahwa teknologi informasi mampu menggeser sistem pola hidup masyarakat dan memicu berbagai gejala sosial, termasuk juga menggeser nilai budaya dan agama. Bahkan dikatakan juga teknologi informasi mengakibatkan perubahan disegala aspek kehidupan individu, keluarga, masyarakat. Bahkan atribut-atribut budaya lokal terancam akibat budaya global, itu disebabkan oleh pengaruh teknologi infomasi yang tidak terkendali.

Generasi muda harus dipersiapkan untuk mampu bertahan ditengah dampak negatif perkembangan teknologi informasi dengan memberikan pengetahuan tentang nilai kearifan lokal. Sehingga dapat memberi arti penting untuk menjaga identitas dirinya dan mampu menjadi counter terhadap budaya tidak sosial dengan kondisi sosial-budaya setempat. Sebagaimana Meliono (2011) mengatakan bahwa ditengah-tengah kemajuan modernisasi dan globalisasi disegala bidang, pemuda Indonesia harus dilengkapi dengan pemahaman tentang berpikir 
Nusantara, kearifan lokal, dan multikulturalisme, sehingga mereka dapat mengembangkan rasa identitasnya.

Nilai kearifan lokal merupakan landasan dasar dalam membentuk individu yang kuat dan berkarakter. Individu terbentuk melalui proses dengan lingkungannya. Peran nilai kearifan lokal menjadi fondasi bagi individu dalam menjalankan setiap proses interaksi dengan lingkungan. Sejak dahulu, nenek moyang kita sebenarnya telah mewariskan beragam pedoman sikap dan perilaku dalam berinteraksi dengan alam dan lingkungan.

Siswadi (2011) menjelaskan bahwa kearifan lokal sering dikonsepsikan sebagai pengetahuan setempat (local knowledge), kecerdasan setempat (local genius), dan kebijakan setempat (local wisdom) oleh karenanya selalu mengandung pengetahuan masyarakat, nilai-nilai sosial, etika dan moral, dan norma-norma secara turun temurun. Desa Melan yang merupakan calon kampung iklim plus -seperti halnya daerah lain-- memiliki berbagai kearifan lokal dalam kehidupan bermasyarakat yang harus dipertegas.
Kearifan lokal menyediakan adanya aspek kohesif berupa elemen perekat lintas agama, lintas masyarakat, dan kepercayaan. Dalam konteks ini, kearifan lokal dapat diartikan sebagai ruang maupun arena dialogis untuk melunturkan segala jenis esklusivitas politik identitas yang melekat di antara berbagai kelompok. Dalam bentuk dialogis tersebut, kearifan lokal membentuk masyarakat menjadi solid dan berbudaya. Namun jika ekslusivitas masih terjadi, maka itu akan menjadi benih dalam membentuk masyarkat yang individualistik dan egosentris.

Pengkajian berkali-kali untuk memahami manusia, dalam ranah konseling khususnya, membuktikan bahwa masalah manusia baik secara individu maupun secara kelompok memiliki signifikansi sosial/sistematik (Cottone, 1992). Ikhwal isu sosial-sistematik ini, khusus di Indonesia, telah dilakukan penelitian dan pembahasan berulang. Perlunya pengkajian budaya nasional dan budaya lokal untuk lebih memahami kehidupan utuh konseli dan untuk membangun prosedur dan teknik konseling yang tepat-budaya, telah berkali-kali 
dibahas (Mappiare-AT., 1990; Mappiare- pilihan yang tepat untuk memotret AT. 1997; Mappiare-AT, Ibrahim, dan fenomena sosial yang kompleks di desa Sudjiono, 2007; $\quad$ Mappiare-AT., Melan, dalam hal ini kearifan lokal.

Fachrurrazy, dan Sudjiono, 2008; Pendekatan etnografi dipilih untuk Wicaksono, 1988; Wuryani, 1988; Irawan memperoleh gambaran yang detail tentang AW, 2018, Ariantini, 2018). Sehingga kearifan lokal masyarakat desa Melan, cukup lugas ketika kajian dan penelitian khususnya melihat bagaimana orang tua mengenai kehidupan sosial-budaya, memberikan pengetahuan (transfer khususnya kearifan lokal, dijadikan knowledge) kepada anak-anaknya serta sebagai topik dalam memahami manusia kearifan yang melngkupi didalamnya. (konseli). Hal ini penting untuk Menurut Muhajir (1996), etnografi sebagai mempertegas siapa sebenarnya individu model penelitian yang mempelajari didalam masyarakat -penegasan identitas-melalui pelayanan konseling. pandangan hidup subjek yang menjadi Sehingga penelitian ini berupaya untuk obyek studi dalam bentuk tulisan. menelusuri dan mengidentifikasi kearifan Sedangkan menurut Mulyana (2001), lokal yang pernah ada dan masih etnografi adalah kegiatan penelitian untuk dipertahankan sampai saat ini sebagai suatu indikator dalam menentukan karakter pribadi ideal konseli.

\section{METODE PENELITIAN}

Penelitian ini menggunakan metode penelitian kualitatif tipe etnografi. Kearifan lokal desa Melan akan diidentifikasi dan dijelaskan secara kualitatif, tidak dalam bentuk angka kuantitatif agar tidak menghilangkan substans fakta di lapangan. Sehingga metodologi etnografi menjadi memahami orang-orang berinteraksi dan bekerjasama melalui fenomena yang diamati dalam kehidupan sehari-hari.

Dapat disimpulkan bahwa metode etnografi adalah kegiatan penelitian untuk memahami orang-orang berinteraksi dan bekerjasama melalui fenomena yang diamati dalam kehidupan sehari-hari. Etnografi bertujuan untuk mengurai suatu budaya secara menyeluruh, yaitu mencakup semua aspek budaya baik yang 
bersifat material maupun yang bersifat kejenuhan data. Pengumpulan data abstrak. Penelitian ini akan membatasi difasilitasi oleh Yayasan Ulin yang sudah aspek budaya dari sisi abstrak. Aspek sejak tahun 2012 melakukan proyek abstrak berupa pengalaman, kepercayaan, pendampingan dan penelitian di desa norma, dan sistem nilai kelompok.

Sumber data yang digunakan dalam penelitian ini adalah sumber primer dan sumber sekunder. Sumber primer atau sumber utama diperoleh dari masyarakat yang mempraktekkan kearifan lokal. Sumber primer dalam penelitian ini adalah tokoh masyarakat di desa Melan. Dalam pandangan Moelong (1995), data utama bisa didapatkan melalui wawancara, pengamatan, atau partisipasi.

Sumber data sekunder digunakan untuk menguatkan data yang ditemukan dari sumber data primer. Sumber data sekunder bisa berasal dari individu yang tidak terlibat dalam objek yang diteliti atau bisa ditemukan dari studi kepustakaan dan sumber tulisan lain yang relevan.

Metode pengumpulan data dilakukan dengan cara observasi partisipatif dan wawancara mendalam. Observasi dilakukan selama beberapa bulan dalam rentan waktu tertentu, untuk mendapatkan Melan. Peneliti tinggal di rumah masyarakat selama beberapa hari secara tidak berurut-urut. Wawancara mendalam dan observasi partisipatif dilakukan secara simultan agar data yang terkumpul bisa valid.

\section{HASIL DAN PEMBAHASAN}

\section{Pribadi yang Setiakawan}

Kesetiakawanan pada masyarakat desa Melan ditunjukkan dengan sikap saling memiliki tanggung jawab sosial satu sama lain. Tanggung jawab sosial tersebut diamati melalui keterlibatan masyarakat dalam berbagai aktivitas, mulai dari gotong royong, kegiatan desa, hingga ketika ada salah satu masyarakat yang sakit atau meninggal. Soliditas tersebut juga ditunjukkan ketika acara pernikahan. Masyarakat bergotong royong untuk mendirikan tenda maupun memasak. Keterlibatan tersebut mengindikasikan sikap kesetiakawanan yang kuat antar satu masyarakat dengan masyarakat yang lain. 
Ketika ada intruksi dari kepala desa untuk melakukan kerja bakti pada hari minggu, masyarakat berbondong-bondong untuk membersihkan lingkungan. Laki-laki bertugas untuk membersihkan lingkungan menggunakan peralatan seperti parang dan sabit, sementara perempuan memasak menyediakan sarapan dan cemilan. Itu semua dilakukan secara swadaya.

Meskipun masyarakat desa Melan sebagian besar merupakan keturunan dari dayak Modang dan hanya sebagian kecil dari suku lain, bukan menjadi hambatan dalam membangun sikap kesetiakawanan. Perbedaan suku di desa tersebut membuat suku minoritas menjadi merasa saling memiliki dan tidak merasa tersisihkan. Tidak heran ketika kesetiakawanan selalu mempererat tali solidaritas diantara masyarakat. Suku dayak Modang pun tidak merasa tersisihkan dari kedatangan para masyarakat pendatang.

Manusia yang ideal, dari sisi kearifan lokal desa Melan, adalah ia yang memiliki sikap kesetiakawanan. Jika dikaitkan dengan bimbingan konseling, maka konseli yang ideal merupakan konseli yang memiliki sikap kesetiakawanan. Ratno Lukitno (2008: 352) berpendapat bahwa kesetiakawanan adalah sebuah perasaan berhubungan secara utuh yang membuat siapapun yang mempunyai perasaan ini menjadi sanak keluarga.

Kesetiakawanan adalah perasaan timbal balik. Ia adalah sebuah perasaan menyadari kebaikan, yang di satu sisi mengikat mereka yang memiliki perasaan ini begitu kuat sehingga mengenyampingkan semua perbedaan yang timbul karena konflik ekonomi atau gradasi sosial, sementara di sisi lain akan mengasingkan mereka yang tidak termasuk ke dalam kelompok mereka. kesetiakawanan adalah keinginan untuk terlibat dengan kelompok lain. Keberadaan rasa kesetiakawanan ini adalah fondasi dari sebuah negara yang stabil dan demokratis.

Memiliki Keyakinan pada Tuhan, Ruh, Alam, dan Manusia

Keyakinan berkaitan mengenai religiusitas yang ada dalam masyarakat desa Melan. Hubungan horizontal (manusia dan alam) dan hubungan vertikal (tuhan) masih terjaga dengan baik. 
Hubungan dengan alam misalnya, nenek moyang mereka. Pemanggilan itu ditunjukkan dengan kebiasaan mereka menggunakan mantra dan sesajen, berupa menjaga alam. Alam dijadikan sebagai ibu bagi manusia, yang memberikan welas asih dan kasih sayang. Setiap musim buah misalnya, masyarakat kewalahan memanen langsat, rambutan, dan durian, karena hasilnya melimpah. Buahnya lebih banyak busuk dipohon dari pada dijual atau dimakan masyarakat. Masyarakat juga percaya bahwa dibalik kelimpahan alam itu, ada roh nenek moyang mereka yang bersemayam diantaranya. Jika alam dirusak, maka nenek moyang akan murka dan bencana akan terjadi.

Kepercayaan masyarakat desa Melan pada hal-hal yang gaib ditunjukkan dengan kebiasaan ritual yang masih sering dilakukan. Lebih banyak ritual diinternal keluarga daripada ritual komunal satu kampung. Menurut informan, hal ini dilakukan untuk menghargai masyarakat pendatang yang bukan berasal dari dayak Modang. Dayak Modang di desa ini memang masih memegang kepercayaan mistis melalui ritual-ritual. Ketika peneliti berkunjung pertama kali, ketua adat melakukan pemanggilan roh di kuburan telur ayam kampung, tuak, dan beberapa perlengkapan lainnya.

Sebagai desa yang jaraknya cukup jauh dengan kantor kecamatan, sekitar 10 $\mathrm{km}$, desa ini masuk dalam kategori terpencil. Dikelilingan oleh kebun sawit, bagi orang awan yang akan berkunjung, bisa saja tersesat. Setelah kantor kecamatan, tidak adalagi rumah masyarakat, hanya kelapa sawit yang berjejar rapi sepanjang mata memandang. Oleh sebab itu, untuk mendukung peribadatan, karena jauh dari keramaian dan pusat pemerintahan, maka pihak desa dan masyarakat bergotong royong untuk membangun rumah ibadah. Ada dua rumah ibadah ditempat ini, yaitu mushollah dan gereja. Dua agama di desa ini, yaitu islam dan kristen, membuat pihak desa memutuskan untuk membangun dua rumah ibadah. Ini menunjukkan keyakinan yang kuat pada agama.

Daudy (1983), menjelaskan bahwa manusia itu pada hakekatnya bukanlah jasad lahir yang diciptakan dari unsurunsur jasad, akan tetapi roh yang ada 
dalam dirinya dan selalu mempergunakan jasad dalam melaksanakan tugasnya.

Kesatuan itu bisa disebut dengan kesatuan ruhani, penyatuan antara jasmani dan ruhani yang dimiliki oleh manusia. Itulah yang membedakan dengan makhlukmakhluk lain. Manusia dapat berbuat dan atau melakukan sesuatu melalui kedua kekuatan tersebut.

Manusia merupakan makhluk sosial dan politik, kesejahteraannya dalam segala hal terpaut dengan kesejahteraan masyarakat. Organisasi individu yang tertinggi adalah masyarakat. Islam mewajibkan untuk membentuk masyarakat dan mengusulkan kepada dunia gagasan kemasyarakatan yang praktis. Dari pada itu manusia harus mengerti tentang lingkungan sekitar dan memanfaatkan sesuai jalan syari'at yang telah ditentukan. Al Qur'an dan as Sunnah selalu meminta agar manusia mengisi hidupnya dengan bekerja untuk mempetahankan kehidupannya, yaitu dengan memanfaatkan apa yang telah Allah ciptakan baginya di muka bumi ini. Dari pandangan Islam, hanya pekerjaan baik dan amal shaleh yang akan mendapatkan pahala. Disamping itu manusia sebagai makhluk yang cerdas akan mampu melaksanaan kegiatan sehariharinya. Tetapi kadangkala ia juga memerlukan bantuan orang lain. Sebenarnya alam tercipta untuk dimanfaatkan oleh manusia. Karena manusia adalah makhluk termulia di bumi ini, maka segala sesuatu memang disediakan untuknya. Diantara tugas manusia, yaitu memanfaatkan alam dan tenaga yang dikandungnya guna memenuhi keperluan dan kebutuhannya dan juga teman-temannya. Hubungan manusia terhadap alam adalah sebagai pemanfaat, dan bukan sebagai saingan. Tidak seharusnya manusia mengeksploitasi alam. Al Quran (2: 29) mengatakan "Ia yang menciptakan bagimu apa yang ada di bumi semuanya"

Sehingga konseli yang baik adalah konseli yang memiliki keyakinan kepada tuhan, ruh, alam, dan manusia, yang diwujudkan dalam bentuk tindakan hubungan baik antara manusia dengan manusia berupa hubungan horizontal, dan hubungan vertikal antara tuhan dan manusia.

\section{Kebiasaan Hidup Sederhana}


Pola hidup sederhana masyarakat desa melan bukan hanya ditunjukkan dari cara berpakaian dan rumah mereka yang sederhana, tapi juga kebiasaan sehari-hari. Hidup sederhana tersebut ditunjukkan dengan berkata dan bertindak apa adanya, tidak berlebihan dalam bertutur kata, ulet dalam bekerja, dan menampilkan hidup yang hemat. Meskipun menampilkan hidup yang hemat, masyarakat desa Melan tidak kikir dalam keuangan. Ketika peneliti berkunjung ke beberapa rumah masyarakat, tidak segan mereka menawarkan kopi dan cemilan, bahkan makan siang. Ketika peneliti ingin pulang kembali ke Samarinda, masyarakat menawarkan hasil kebun mereka untuk peneliti bawa.

Masyarakat desa Melan tidak berlebihan dalam bertutur kata. Mereka menampilkan keaslian mereka sebagai manusia desa. Berkata dan bertindak apa adanya, sesuai antara perkataan dan tindakan. Ketika peneliti berjanji kepada masyarakat untuk bertemu, mereka menepati janjinya, bukan hanya itu, dalam beberapa kejadian, masyarakat berusaha untuk menepati janji.
Pola hidup sederhana terdiri atas dua pengertian pokok, yaitu pola hidup dan sederhana. Wijaya (2014: 119) mengemukakan pola hidup adalah cara berperilaku sehari-hari, sejak bangun tidur sampai tidur lagi. Kegiatan berperilaku tersebut misalnya, tidur, makan, mandi, olahraga, dan belajar. Pola hidup dapat disamakan dengan kebiasaan, jika memiliki kebiasaan yang buruk berarti juga memiliki pola hidup yang buruk, dan begitu pun sebaliknya. Kebiasaan yang baik menandakan telah melakukan pola hidup yang baik. Pola hidup sederhana juga dapat ditunjukkan dalam sikap hidup berikut ini; tidak mudah menaruh curiga kepada orang lain, tidak suka pamer, tidak sombong, jujur, suka menolong.

Konseli yang baik adalah ia memiliki kebiasaan pola hidup yang sederhana dan tidak menunjukkan sikap yang angkuh dan sombong dengan apa yang sudah ia miliki.

\section{KESIMPULAN}

Temuan penelitian yang sudah dijabarkan pada bagian sebelumnya, yang merupakan jawaban atas rumusan 
masalah, merupakan upaya untuk mengidentifikasi pribadi ideal konseli dalam kearifan lokal di desa Melan. Setidaknya terdapat tiga pribadi ideal konseli yang ada di desa Melan, yaitu memiliki sikap kesetiakawanan, memiliki keyakinan pada tuhan dan sifatnya metafisik, dan terbiasa hidup dalam kesederhanaan.

Saran dari penelitian ini yaitu diharapkan dijadikan sebagai rekomendasi dalam merancang indikator pribadi ideal konseli atau siswa di desa Melan hingga skala tingkat Kecamatan Long Mesangat. Diperlukan penelitian lanjutan untuk memahami kondisi mendalam mengenai desa Melan.

\section{REFERENSI}

Alfian, Magdalia. (2013). "Potensi Kearifan lokal dalam Pembentukan Jati Diri dan Karakter Bangsa". Prosiding The 5 thn ICSSIS; "Ethnicity and Globalization", di Jogyakarta pada tanggal 13-14 Juni 2013.

Asmani, J, M. 2009. Jurus-Jurus Belajar Efektif Untuk SMP dan SMA. Jogjakarta: Diva Press

Cottone, R.R. , (1992). Theories and Paradigms of Counseling and
Psychotherapy. Boston: Allyn and Bacon.

Desmita. 2014. Psikologi Perkembangan Peserta Didik. Bandung: PT. Remaja Rosdakarya.

Effendy. (2008). Dinamika Komunikasi. Bandung: PT. Remaja Rosdakarya.

Fajarini, U. (2014). Peranan Kearifan Lokal Dalam Pendidikan Karakter. Universitas Islam Negeri ( UIN). Jakarta. Diakses pada tanggal 20 Oktober 2015:hal:123-125.

Gibson \& Mitchell. (2011). Bimbingan Dan Konseling. Alih Bahasa Yudi Santosa. Pustaka Pelajar: Yogyakarta.

Hanurawan, F. (2012). Metode Penelitian Kualitatif: Dalam Ilmu Psikologi. Surabaya: Pusat Studi Peningkatan Kinerja Masyarakat (LPPM) UniversitasAirlangga.

Hariyanto. (2014). Asessmen Pendidikan. Bandung: PT Remaja Rosdakarya

Istiawati, Novia Fitri. (2016). Pendidikan karakter berbasis niali-nilai kearifan lokal adat ammatoa dalam menumbuhkan karakter konservasi. e-ISSN. 10 (1). Hlm 117

Irawan, AW., (2018). Identitas Remaja Mandar dan Konstuksi Bibliokonseling Bermuatan Budaya Sebagai Teknik KIPAS (Kajian Fenomenologi Terhadap 
Pappasang Orang Tua). Tesis. Malang : Universitas Negeri Malang

Mappiare-AT, A., (1997). Faktor-faktor Penunjang Kesuksesan Fungsi Ekonomi Keluarga dalam Gerakan BSD selaku Landasan Bimbingan dan Konseling Keluarga: Studi Kasus di Desa Karangmojo, Kecamatan Karangmojo, Kabupaten Magetan. Malang: Fakultas Ilmu Pendidikan, IKIP MALANG.

Mappiare-AT, A., Ibrahim, A.S., dan Sudjiono, (2007). 'Kultur Konsumsi Remaja dan Upaya Bimbingannya: Studi Perspektif Posmodern mengenai Pembelanjaan Pelajar dalam Kota Metropolitan Pantai Indonesia untuk Pengembangan Media Bibliokonseling.' Laporan Penelitian HB-DP2M, Lemlit Universitas Negeri Malang.

Mappiare-AT., A., Fachrurrazy, dan Sudjiono, 2008. 'Kultur Konsumsi Remaja dan Upaya Bimbingannya: Studi Perspektif Posmodern mengenai Kecakapan Belanja dan Kearifan Kultural pada Pelajar Metropolitan Pantai Indonesia untuk Pengembangan Media Bibliokonseling.' Laporan Penelitian HB-DP2M, Lemlit Universitas Negeri Malang.

Meliono, I. 2011. Understanding The Nusantara Thought and Lokal Wisdom as an Aspect of The
Indonesian Education. International Journal for Historycal Studies, 2(2): 221-234.

Miles \& Huberman, (1992). Analisa Data Kualitatif. Jakarta: Universitas Indonesia Press.

Moleong, L. Metode Penelitian Kualitatif. (Bandung. Rosdakarya, 1995. Cet. Ke-v) hal 112.

Muhajir, N. Metodologi Penelitian Kualitatif, (Yogyakarta Rake Surasin, Edisi IV 1996) Hal. 94.

Mulyana, D. 2001. Metodologi Penelitian Kualitatif Paradigma Baru Ilmu Komunikasi dan Ilmu Sosial Lainnya. Bandung: Rosdakarya.

Palmer, Stephen \& Laungani, P. (2008). Counseling in a Multicultural Society. London : Sage Publisher.

Saputro. (2011). Piil Pesenggiri: Etos dan Semangat KeLampungan. Bandar Lampung: Jung Foundation Lampung Heritage dan Dinas Pendidikan Lampung.

Siswadi, 2001. Kearifan Lokal dalam Melestarikan Mata Air (Studi Kasus di Desa Purwogondo, Kecamatan Boja, Kabupaten Kendal). Jurnal Ilmu Lingkungan. Volume 9 issue 2 63-68

Strauss \& Corbin. 1990 Basis of Qualitative Research: Grounded Theory Procedure and Techniques. London: Sage Publications. 
Supriadi, D. (2001). Konseling Lintas - Wicaksono, R., (1988). "Gambaran Budaya: isu-Isu Dan Relevansi Di Indonesia. UPI: Bandung.

Supriatna, M. (2009). Materi PLPG Sertifikasi Guru. FIP: UPI Bandung. Bimbingan dan Konseling dalam kontek budaya Indonesia". Bina Bimbingan : Media Psikologi Pendidikan \& Bimbingan, 3, II: 5 -8 .

(2011). Bimbingan dan Konseling Berbasis Kompetensi. Jakarta : PT. Raja Grafindo Persada

Wahyudi, Agus. (2014). Pesona Kearifan Jawa. Yogyakarta: Dipta

Wibowo, Agus. (2015). Pendidikan Karakter Berbasis Kearifan Lokal di Sekolah. Yogyakarta: Pustaka Pelajar.

Wuryani, S. E., (1994). "Konseling dengan pendekatan ekonomi". Bina Bimbingan: Majalah Pembinaan Bimbingan dan Konseling Pendidikan, 1, IX: 31 - 41. 